\title{
Evaluation of Health Locus of Control of Individuals with Type 2 Diabetes
}

\section{Tip 2 Diyabetli Bireylerin Sağlık Kontrol Odaklarının Değerlendirilmesi}

\author{
Mustafa Kılıç ${ }^{1}$, Selda Arslan*l
}

\begin{abstract}
Introduction/Aims: The locus of control used in the management of chronic diseases is used to explain the different behaviors individuals exhibit in relation to disease This study, was done with the purpose of investigating the health locus of control and affecting factors of diabetic individuals. Methods: This study was a descriptive and cross-sectional study. Data were collected from 325 diabetic individuals living at city center. The questionnaire form and Multidimensional Health Locus of Control Scale were used in collecting data. Results: The average age of the patients participated to research was $53.3 \pm 8.0$ years and $51.4 \%$ of them were women, $88.9 \%$ of them were married, $69.8 \%$ of them were primary school graduated and $43.7 \%$ of them were housewives. From scale; it was determined that they got $25.3 \pm 6.8$ points from Internal Health Locus of Control sub-dimension, 27.3 \pm 4.7 points from Strong Others Internal Health Locus of Control sub-dimension, 17.9 \pm 5.5 points from Chance Locus of Control sub-dimension. Internal health locus of control; marital status, education level, person living together, regular exercise, regular diabetes diet application status were found meaningful ( $\mathrm{p}<0.05)$. Powerful others health locus of control; adhering to regular diabetes diet, taking regular health checks, Chance health locus of control; marital status, person living, number of individuals in family, status of compliance to regular diabetes diet were found meaningful $(\mathrm{p}<0.05)$. Conclusion: It was found that the individuals had mainly external control locus, it's suggested to enhance patients' internal health locus of control by nurses for the purpose of providing independency.
\end{abstract}

Keywords: Diabetes, nursing, health locus of control

\section{ÖZET}

Giriş/Amaç: Kronik hastalıkların yönetiminde kullanılmakta olan kontrol odağı, bireylerin hastalık karşısında sergilemiş oldukları farklı davranışları açıklamak için kullanılmaktadır. Bu çalışma, diyabetli bireylerin sağlık kontrol odaklarını ve etkileyen faktörleri incelemek amacıyla yapılmıştır. Yöntem: Araştırma, tanımlayıcı ve kesitsel türde bir çalışmadır. Veriler, kent merkezinde yaşayan 325 diyabetli bireyden toplanmıştır. Verilerin toplanmasında anket formu ve Çok Boyutlu Sağlık Kontrol Odağı Ölçeği kullanılmıştır. Bulgular: Çalışmaya katılan hastaların yaş ortalaması 53.3 \pm 8.0 yıl olup, \%51.4'ü kadın,

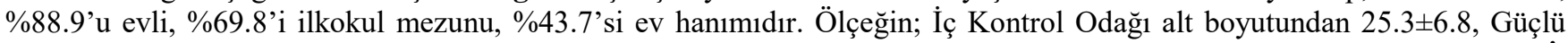

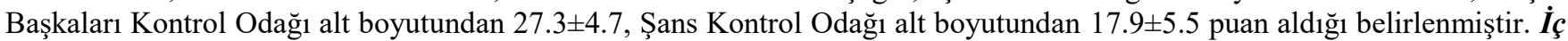
kontrol odağında; medeni durum, öğrenim durumu, yaşadığ kişi, düzenli egzersiz yapma, düzenli diyabet diyeti uygulama durumu anlamlı bulunmuştur ( $<<0.05)$. Güçlï başkaları kontrol; düzenli diyabet diyetine uyma, düzenli sağlık kontrolü yaptırma durumu, Şans kontrol odağında ise yaş, medeni durum, yaşadığı kişi, ailedeki birey sayısı, düzenli diyabet diyetine uyma durumu anlamlı bulunmuştur $(\mathrm{p}<0.05)$. Sonuç: Hastaların daha çok dış kontrol odağına sahip oldukları saptanmış, hemşireler tarafından hastaların bağımsızlıklarını sağlamak amacıyla iç kontrol odaklarının geliştirilmesi önerilmektedir.

Anahtar kelimeler: Diyabet, hemşirelik, sağlık kontrol odağı

Received / Geliş tarihi: 12.02.2018 Accepted / Kabul tarihi: 26.04.2018

${ }^{1}$ Selçuk Üniversitesi Sağlık Bilimleri Fakültesi Konya-Türkiye

*Address for Correspondence / Yazışma Adresi: Selda Arslan, Selçuk Üniversitesi Sağlık Bilimleri Fakültesi Konya-Türkiye,

E-mail: seldayarali@hotmail.com

Kılıç ve Arslan. Tip 2 Diyabetli Bireylerin Sağlık Kontrol Odaklarının Değerlendirilmesi. TJFMPC, $2018 ; 12$ (2): 126-135. DOI:

10.21763/tjfmpc.432547 


\section{GíRiș}

Pek çok bilişsel motivasyon teorisinin merkez prensiplerinden biri, insanların yaşamlarının önemli alanlarını kontrol etme isteğidir. ${ }^{1}$ Kontrol odağ insanların yaşamlarını etkileyen olayları kendi beceri, kişilik ve davranışlarını şans, kader, tanrı, içgüdüler ve dişsal etmenlerin sonucu olarak algılama biçimidir. ${ }^{2,3}$ Rotter tarafından kuramsallaştırılan kavrama göre insan; hayatına tesir edebilen yaşam deneyimlerini etkileyebilme yeteneğine sahip, bilinçli bir varlık olarak tanımlanmıştır. ${ }^{2}$ Fakat dış uyarıcılar ve pekiştireçler de insan davranışlarını etkileyebilmekte, insanlar bunu iç denetim ve dış denetim odağı olmak üzere iki şekilde algılamaktadırlar. İç denetim odaklı insanlar, pekiştirmenin kendi davranışlarına bağlı olduğunu düşünerek kendi yaşamlarından sorumlu olduklarını düşünürler ve buna uygun davranışlar ortaya koyarlar. ${ }^{1,2,4,5}$ İç denetim odaklı insanların hayatta daha başarılı olduğ $\mathrm{u}^{5}$ ve yaşamlarını kontrol edebilmelerine ilişkin inançlarının yanında olumsuz olaylarla başa çıkma kapasitelerinin de yüksek olduğu belirtilmiştir. ${ }^{2,4}$ Dış denetim odaklı insanlar ise, davranışlarının sonucunda elde edeceği yarar veya zararların aslında şans, kader ya da bir başkasının etkisine bağlı olarak ortaya çıkacağına inanırlar. Bu durumda bir davranışın algılanması, sonucunun öngörülemediği, anlamlandırılamadığ 1 durumlarda dış kontrole dair şans/kader olarak alg1lanabilmektedir. $\quad 1,2,4 \quad \mathrm{Bu}$ bireyler kendi sonuçlarını kontrol edemez ve diğer faktörlerin etkisinde kalırlar, güçsüz ve yabancılaşmış kişilerdir bu yüzden kendi durumlarını değiștirmek veya iyileştirmek için daha az gayret gösterirler. ${ }^{2,4,5}$

Genellikle kronik hastaların, kendi yönetimlerini değerlendirmeleri için kullanılan kontrol odağ1 kavramı, günlük hayatta hastaların yüzleşmek zorunda oldukları çeşitli durumlardaki davranışlarını gösterir. ${ }^{6}$ Diyabete uyum sağlamak hastalar için karmaşık bir süreçtir. Bugüne kadar diyabet alanında fiziksel ve psikolojik faktörlere ilişkin çok sayıda araştırma yapılmıştır, ancak diyabet hastalarında kontrol odağının belirlenmesine, bunun tedavi ve bakım üzerindeki etkilerinin incelenmesine yönelik çalışma sayısı sınırlıdır. ${ }^{6-8}$ Diyabetin hemşirelik yönetimi, sadece psikososyal sağlık problemlerinin prevelansı üzerine odaklanmayı değil, aynı zamanda sağlık kontrol odakları gibi subklinik göstergeler üzerine de yeterince odaklanmayı gerektirir. ${ }^{8}$ Sağlık kontrol odağının, hastalığa uyumda etkili olduğu, ${ }^{8,9}$ iç kontrol odağı yüksek olan hastaların tedaviye uyumlarının daha iyi olduğu bildirilmiştir. ${ }^{7}$ Ayrıca, iç kontrol odağının daha iyi fiziksel ve mental sağlık durumu ve ileriye dönük olumlu sağlık davranışlarıyla ilişkili olduğu belirtilmektedir. ${ }^{10}$ Diyabette sağlık kontrol odakları ile ilgili çalışmalarda, iç kontrol odağına sahip bireylerde düzenli diyet ve egzersiz oranlarının yüksek olduğu, ${ }^{12,13}$ iç kontrol odağının HbA1c düzeyi ile ilişkili11 öz-etkililik ve öz bakım davranışlarıyla pozitif bir etkileşim içerisinde olduğu görülmüştür. ${ }^{14}$

Ülkemizde, sağlık kontrol odağı algısı üzerinde yapılan araştırmalar incelendiğinde, genellikle eğitim bilimleri ve psikoloji gibi alanlarda yapıldığı, sağlıkla ilgili olarak diyabet alanında ise sınırlı sayıda ${ }^{3}$, araştırmanın olduğu görülmüştür. Sağlık kontrol odakları, çeşitli durumlardan ve faktörlerden etkilenebilmektedir. ${ }^{8,9,14}$ Hemșirelerin, diyabetli bireylerin kendi sağlıklarını yönetebilmelerini desteklemesi ya da cesaretlendirebilmesi için, diyabetli bireylerin sağlık kontrol odaklarının belirlenmesi gerekmektedir. $^{8}$ Sağlık kontrol odağının davranışların belirleyicisi olduğu dikkate alındığında, ülkemizde tip 2 diyabetli bireylerin kontrol odaklarına ilişkin yapılmış çalışmalara rastlanamaması nedeniyle bu çalışmada tip 2 diyabetli bireylerin sağlık kontrol odaklarının belirlenmesi amaçlanmıştır.

\section{YÖNTEM}

\section{Araștırma Evreni ve Örneklemi}

Tanımlayıcı ve kesitsel tipte tasarlanan bu çalışma, her bölgeyi temsil etmesi amaciyla Konya ilinin merkez ilçeleri olan, Selçuklu, Meram ve Karatay'da bulunan ve kura yöntemiyle belirlenen üç aile sağlığı merkezinde yürütülmüştür. Diyabetli bireylerin yaşadıkları yerde değerlendirilmek istenilmesi, sağlık kontrol odaklarına doğrudan etki edecek unsurların (sağlık profesyonelleri, hastane ortamında tedavinin düzenli yapılması gibi durumlar) bulunmaması gibi durumlar göz önüne alındığından, araştırmanın aile sağlığı merkezinde yapılmasına karar verilmiştir. Araştırma evrenini 2015 yılı içinde, belirlenen aile hekimliği otomasyon sistemine kayıtlı 2800 diyabetli birey oluşturmaktadır. Örneklem sayısı için \%95 güç, 0.05 önemlilik değeri ve 0.10 'luk beklenen etkiyle bağımsız değişken sayısı maksimum 20 kabul edilerek, örneklem büyüklüğü 325 olarak belirlenmiştir. ${ }^{15} 18-65$ yaş aralığında, en az ilkokul mezunu ve en az 6 aydır diyabet tanısı almış olan ve iletişim problemi bulunmayan bireyler çalışmaya dahil edilmiştir. Verilerin toplanmasında, kurum hekimleri aracılığıla diyabetli bireyler bilgilendirilerek, bilgilendirme sonrasında ilk gelen diyabetli bireyden başlanarak gelen tüm diyabetli bireyler araştırmaya alınmıştır. Örneklem hesabında belirlenen sayıya ulaşıldığında, veri toplama ișlemi sona erdirilmiştir. Araştırma verileri, Haziran 2015Aralık 2015 tarihleri arasında 325 birey üzerinden toplanmıştır. Verilerin toplanmasında, formlar diyabetli bireylere dağıtılarak kendilerinin işaretlemeleri istenmiş; ancak okuma konusunda 
yardım isteyen bireylere de sorular okunarak yardımcı olunmaya çalışılmıştır. Veri toplama esnasında formlar kontrol edilerek, boş bırakılmaması için çaba gösterilse de, 18 kişinin verileri, yaş veya eksik doldurma gibi nedenlerle araştırmaya dahil edilmemiştir. Araştırmayı kabul eden bireylerin hepsinden gönüllü onamları alınmış, onam vermeyip çalışmaya katılmayı reddeden bireylere ilişkin bir sayı tutulmamıştır. Meram bölgesinden veriler toplanırken; diyabetli bireylerin Aile Sağlığı Merkezi başvuru oranlarının az olması, araştırmacının zamanının kısıtlı olması gibi nedenlerle bu bölgeden yeterli veri toplanamamış, bu nedenle verilerin analizinde bölgesel karşılaştırmalar yapılamamıştır.

\section{Veri Toplama Araçları}

Anket Formu: Araştırmacılar tarafindan literatür incelenerek ${ }^{4,16,17}$ hazırlanan formda, bireylerin sosyodemografik (yaş, cinsiyet, medeni durum, eğitim durumu, meslek, ekonomik durum algısı, birlikte yaşadığı kişi, ailedeki birey sayısı), sağlık ve hastalık özelliklerine (beden kitle indeksi, sigara ve alkol kullanma durumu, diyabet tanı süresi, HbA1c düzeyi, ailede diyabet varlığı, diyabet eğitimi alma, yeterli eğitim aldığını düşünme, düzenli sağlık kontrolü yaptırma, diyabet tedavi türü, ilaçları düzenli kullanma, düzenli egzersiz yapma ve düzenli diyabet diyeti uygulama) ilişkin sorular bulunmaktadır. Bireylerin boy, kilo değerleri araştırmacı tarafindan kurumda ölçülmüş, HbA1c düzeyleri için; kan tahlilleri yanında olan hastaların değerlerine bakılmış, kan tahlili yanında olmayan hastaların sözel bildirimleri dikkate alınmamış, bu hastalara tekrar invaziv bir girişim yapılmamıştır.

\section{Çok Boyutlu Sağlık Kontrol Odağı} Ölçeği: Wallston ve arkadaşları (1978) tarafından geliştirilen, 18 maddeden, 3 alt boyuttan oluşan Çok Boyutlu Sağlık Kontrol Odağı Ölçeği C formu kullanılmıştır. İç, güçlü başkaları ve şans kontrol odaklarından oluşan ölçek, 18 maddeden oluşmaktadır $^{18}$. Her alt boyut altışar madde üzerinden 6-36 arasinda puanlanır. Alt boyutlar arasında; en yüksek alt boyut puanı üzerinden kişilerin o alt boyuta ilişkin odağına sahip olduğu şeklinde değerlendirilir. Ölçeğin Türkçe geçerlilik güvenirliliği Üstündağ-Budak ${ }^{19}$ tarafından yapılmıştır. Çok Boyutlu Sağlı Kontrol Odağ1 Ölçeğinin iç-tutarlılık katsayısı 0.63 olarak bulunmuştur. Ölçekte yer alan maddelerin faktör yükleri 0,41 ile 0,79 arasındadır. Açıklanan toplam varyans 47,4 dür. Bu çalışmada, Cronbach alfa 0.61 olarak bulunmuştur.

\section{Verilerin Analizi}

Veriler SPSS 20 programı kullanılarak değerlendirilmiş; sayı, yüzde, ortalama, standart sapma olarak özetlenmiştir. Normal dağılım Kolmogorov-Smirnov testi ile değerlendirilmiş ve analizlerde bağımsız gruplarda $t$ testi ve tek yönlü varyans analizinden yararlanılmıştır. Farklılı̆̆ aramak için Tukey HSD ve Dunnett T3 testleri kullanılmış, anlamlılık $\quad p<0.05$ olarak değerlendirilmiştir. Beden kitle indeksi kilo/boy ${ }^{2}$ $\left(\mathrm{kg} / \mathrm{m}^{2}\right)$ olarak hesaplanmış ve sınıflandırılmıştır. HbA1c düzeyi ise, aritmetik ortalamalarına göre gruplandırılmıştır.

\section{Araştırmanın Etik Boyutu}

Verilerin toplanması için, Selçuk Üniversitesi Sağlık Bilimleri Fakültesi Girişimsel Olmayan Klinik Araştırmalar Etik Kurulundan 2015/31 sayılı karar ile ve Konya Halk Sağlığ1 Müdürlüğünden $86104336 / 600$ sayılı yazılı izinler alınarak yapılmıştır. Çalışmaya katılan bireylere, araştırmanın amacı anlatılarak sözlü ve Gönüllü Bilgilendirme Formu imzalatılarak yazılı onamları alınmıştır.

\section{BULGULAR}

Çalışmaya katılan hastaların yaş ortalaması $53.3 \pm 8.0$ (min:30-max:65) yıl olup, \%51.4'ü kadın, \%88.9'u evli, \%69.8'i ilkokul mezunu, \%43.7'si ev hanımıdır. Hastaların \%63.4'ü algıladığı ekonomik durumunu orta olarak değerlendirirken, \%58.8'inin eş ve çocukları ile birlikte yaşadığı ve ailede ortalama birey sayısının $3.8 \pm 1.8$ olduğu belirlenmiştir. Araştırmaya katılan hastaların bazı alışkanlıklarına göre dağılımı incelendiğinde; \%76.4'ünün sigara kullanmadığı, kullananların ortalama kullanma süresinin $15.5 \pm 7.9$ y1l olduğu, \%98.5'inin alkol kullanmadığı, kullananların ortalama kullanma süresinin $12.6 \pm 4.8$ yıl olduğu, \%52.6'sının düzenli egzersiz yapmadığ 1 , \%66.5'inin diyabet diyetine uymadı̆̆ 1 , \%80.9'unun sağlık kontrollerini düzenli yaptırdığı bulunmuştur. Araştırmaya katılan hastaların ortalama tanı süresi $8.7 \pm 7.2$ yıl, HbA1c düzeyi $\% 8.2 \pm 1.1$ 'dir. Hastaların $\% 54.2$ 'sinin ailesinde diyabet olmadığ $1, \% 87.7$ 'sinin diyabet eğitimi aldığ1, eğitim alanların \%82.5'inin eğitimi hekimden aldığı, \%76.8'inin aldığı eğitimin yeterli olduğunu düşündüğü saptanmıştır. Hastaların $\% 69.2$ 'si sadece oral anti diyabetik kullandığını, $\% 88$ 'i düzenli ilaçlarını kullandıklarını belirtmişlerdir.

Çok Boyutlu Sağlık Kontrol Odağı Ölçeği; İç Kontrol Odağı alt boyutundan ortalama 25.3 \pm 6.8 , Güçlü Başkaları Kontrol Odağı alt boyutundan ortalama 27.3 \pm 4.7 , Şans Kontrol Odağ boyutundan ortalama $17.9 \pm 5.5$ puan aldiğ 1 belirlenmiştir (Tablo 1). Hastaların, Çok Boyutlu Sağlık Kontrol Odağı Ölçeğinin İç Kontrol Odă̆ $ı$ alt boyutunun sosyodemografik özellikler ile ilişkisi değerlendirildiğinde yaş ve cinsiyet değişkenlerinin 
puan ortalamasının benzer olduğu belirlenmiştir $(p>0.05)$. Medeni durumu evli olanların bekar/dul/boşanmışlara göre, ortaokul ve üstü mezun olanların ilkokul mezunu olanlara göre, ailesi veya başka kişiler ile yaşayanların yalnız yaşayanlara, ailede birey sayısı üç ve üzerinde olanların bir ve iki olanlara göre puan ortalaması anlamlı olarak yüksek bulunmuştur $(p<0.05)$. Güçlü Başkaları Kontrol Odağı alt boyutunda cinsiyet, medeni durum, eğitim durumu, yaşadığı kişi değişkenleri puan ortalamalarının benzer olduğu bulunmuşken, yaş ve ailedeki birey sayısı arasında anlamlı fark bulunmuştur. Tukey HSD testine göre ise, farklılığın 52 yaş ve üstünde olanlardan kaynaklandiğ 1 (28.3 \pm 4.1$)$; bu grubun puan ortalamasının 41-51 yaş $(26.3 \pm 5.2)$ ve $30-40$ yaş aralığında (24.4 \pm 4.9$)$ daha yüksek olduğu görülmektedir $(p<0.05)$. Ailedeki birey sayısı bir veya iki olanların, birey sayısı üç ve üzerinde olanlara göre puan ortalaması yüksek bulunmuştur $(p<0.05)$. Şans kontrol odă̆ eğitim durumu puan ortalamalarının benzer $(p>0.05)$; yaş medeni durum, yaşadığı kişi ve ailedeki birey sayısının puan üzerine etkisinin anlamlı olduğu bulunmuştur. Tukey HSD testine göre, 52 yaş ve üstünde olanların $(18.2 \pm 5.7)$ ve 41 51 yaş $(18.2 \pm 5.1)$ aralığında olanlar benzer puan ortalamasına sahip olduğu görülmüş ve bu grupların ve 30-40 yaş aralığında (14.2 \pm 5.7$)$ olanlara göre puan ortalamasının yüksek olduğu bulunmuştur $(p<0.05)$. Bekar/dul/boşanmışların evli olanlara göre, yalnız yaşayanların, ailesi veya diğer kişiler ile yaşayanlara göre puan ortalaması yüksek bulunmuştur $(p<0.05)$ (Tablo 2$)$.

\begin{tabular}{|lcccc|}
\hline \multicolumn{4}{|l}{ Tablo 1. Hastaların çok boyutlu sağı̆ık kontrol odağı ölçeği alt boyutlarından aldıkları puanların dağılımı } \\
\hline & Ort \pm ss & Ortanca & En Küçük & En Büyük \\
\hline Çok Boyutlu Sağlık Kontrol Odağı Ölçeği & & & & \\
İç Kontrol Odağı & $25.3 \pm 6.8$ & 27.0 & 6 & 36 \\
Güçlü Başkaları Kontrol Odağı & $27.3 \pm 4.7$ & 27.0 & 6 & 36 \\
Şans Kontrol Odağı & $17.9 \pm 5.5$ & 19.0 & 6 & 36 \\
\hline
\end{tabular}

Ort: Aritmetik Ortalama ss: Standart Sapma

Hastaların beden kitle indeksi ve bazı alışkanlıklarına göre, Çok Boyutlu Sağlık Kontrol Odağı Ölçeği alt boyutlarının puan dağılımı incelendiğinde, $\dot{\boldsymbol{I}} \boldsymbol{c}$ kontrol oda $\breve{g} \boldsymbol{l}$ alt boyutunun beden kitle indeksi, sigara kullanma durumu ve düzenli sağlık kontrolü yaptırma puan ortalamasının benzer olduğu ( $p>0.05)$, düzenli egzersiz yapma, düzenli diyabet diyeti uygulama durumunun ise, puan ortalamasında farklılık olduğu bulunmuştur $(p<0.05)$. $\mathrm{Bu}$ farklılığın nedenine bakıldığında, düzenli egzersiz yapanların $(28.4 \pm 4.8)$ ve bazen yapanların $(28.2 \pm 5.2)$ puan ortalamasinın benzer ve her iki grubunda düzenli egzersiz yapmayanlara (22.6 \pm 7.2$)$ göre puan ortalamasının yüksek olduğu bulunmuştur. Düzenli diyabet diyeti uygulayanların (26.9 \pm 6.2$)$, uygulamayanlara $(22.1 \pm 7.0)$ göre puan ortalamas1 yüksek bulunmuştur. Güçlü Başkaları Kontrol Odă̆ında beden kitle indeksi açısından grupların puan ortalamaları arasında anlamlı fark olduğu, Dunnett T3 testine göre ise, farklılığın bütün gruplar arasında olduğu, hafif kilolu olanların $(28.6 \pm 4.3)$ en yüksek puan ortalamasına, normal kiloda olanların $(23.3 \pm 6.0)$ ise en düşük puan ortalamasına sahip olduğu görülmektedir. Düzenli egzersiz yapanların ve bazen egzersiz yapanların puan ortalamasının benzer ve düzenli egzersiz yapmayanlara göre yüksek olduğu bulunmuştur. Düzenli diyabet diyetine uyanların (28.0 \pm 4.2$)$, uymayanlara göre $(26.0 \pm 5.3)$, düzenli sağlik kontrolü yaptıranların $\quad(28.0 \pm 4.6)$ yaptırmayanlara göre $(24.5 \pm 4.2)$ puan ortalamas1 yüksek bulunmuştur. Sigara kullanma durumuna göre ise grupların puan ortalamasının benzer olduğu bulunmuştur $(p>0.05)$. Şans kontrol odă̆ında, sigara kullanma ve düzenli sağlık kontrolü yaptırma durumları puan ortalamalarının benzer olduğu bulunmuştur $(p>0.05)$. Beden kitle indeksine göre, obez olanların puan ortalamasının hafif kilolu ve normal kiloda olanlarla benzer olduğu ve hafif kilolu olanların normal kiloda olan gruptan daha yüksek olduğu bulunmuştur $(p<0.05)$. Düzenli egzersiz yapma durumuna göre oluşturulan gruplar arasında, puan ortalamasına göre farklılığın anlamlı olduğu, düzenli egzersiz yapanların puan ortalamasının en yüksek, bazen yapanların ise en düşük olduğu bulunmuştur. Düzenli diyabet diyetine uymayanların $(19.2 \pm 4.6)$ uyanlara $(17.3 \pm 5.9)$ göre ortalamas1 yüksek bulunmuştur $(p<0.05)$. Sigara kullanma ve düzenli sağlık kontrolü yaptırmaya göre ise grupların puan ortalamasının benzer olduğu bulunmuştur $(p>0.05)$ (Tablo 3). 


\begin{tabular}{|c|c|c|c|c|c|}
\hline & $\mathbf{n}$ & $\%$ & $\begin{array}{c}\text { İc Kontrol } \\
\text { Odağı } \\
\text { Ort } \pm \text { SS }\end{array}$ & $\begin{array}{c}\text { Güçlü Başkaları } \\
\text { Kontrol } \\
\text { Odağı } \\
\text { Ort } \pm \text { SS }\end{array}$ & $\begin{array}{c}\text { Şans Kontrol } \\
\text { Odağı } \\
\text { Ort } \pm \text { SS }\end{array}$ \\
\hline \multicolumn{6}{|l|}{ Yaş } \\
\hline $30-40^{\mathrm{a}}$ & 20 & 6.2 & $26.8 \pm 4.3$ & $24.4 \pm 4.9$ & $14.2 \pm 5.7$ \\
\hline $41-51^{b}$ & 115 & 35.4 & $26.1 \pm 6.4$ & $26.3 \pm 5.2$ & $18.2 \pm 5.1$ \\
\hline 52 ve üzeri ${ }^{c}$ & 190 & 58.5 & $24.7 \pm 7.3$ & $28.3 \pm 4.1$ & $18.2 \pm 5.7$ \\
\hline Test ve $\mathrm{p}$ değeri & & & $\begin{array}{c}F=2.137 \\
p=0.120\end{array}$ & $\begin{array}{c}\mathrm{F}=10.815 \\
\mathbf{p}<\mathbf{0 . 0 0 1} \\
\mathrm{a}, \mathrm{b}<\mathrm{c}, \mathrm{p}=0.001 *\end{array}$ & $\begin{array}{c}\mathrm{F}=5.011 \\
\mathbf{p}=\mathbf{0 . 0 0 7} \\
\mathrm{a}<\mathrm{b}, \mathrm{c} \\
\mathrm{p}<0.05^{*}\end{array}$ \\
\hline \multicolumn{6}{|l|}{ Cinsiyet } \\
\hline Kadın & 167 & 51.4 & $25.0 \pm 6.3$ & $27.7 \pm 4.9$ & $17.9 \pm 5.7$ \\
\hline Erkek & 158 & 48.6 & $25.6 \pm 7.4$ & $26.9 \pm 4.5$ & $18.0 \pm 5.4$ \\
\hline Test ve $\mathrm{p}$ değeri & & & $\begin{array}{c}\mathrm{t}=-0.744 \\
\mathrm{p}=0.458\end{array}$ & $\begin{array}{l}\mathrm{t}=1.489 \\
\mathrm{p}=0.138\end{array}$ & $\begin{array}{l}\mathrm{t}=-0.266 \\
\mathrm{p}=0.790\end{array}$ \\
\hline \multicolumn{6}{|l|}{ Medeni durum } \\
\hline Evli & 289 & 88.9 & $25.7 \pm 6.7$ & $27.3 \pm 4.5$ & $17.6 \pm 5.6$ \\
\hline Bekar/dul/boşanmış & 36 & 11.1 & $22.4 \pm 7.5$ & $28.1 \pm 6.0$ & $20.8 \pm 4.4$ \\
\hline Test ve $\mathrm{p}$ değeri & & & $\begin{array}{l}t=2.645 \\
\mathbf{p}=\mathbf{0 . 0 0 9}\end{array}$ & $\begin{array}{c}\mathrm{t}=-0.989 \\
\mathrm{p}=0.323\end{array}$ & $\begin{array}{c}\mathrm{t}=-3.234 \\
\mathbf{p}=\mathbf{0 . 0 0 1}\end{array}$ \\
\hline \multicolumn{6}{|l|}{ Eğitim Durumu } \\
\hline İlkokul & 227 & 69.8 & $24.4 \pm 7.2$ & $27.7 \pm 4.3$ & $18.0 \pm 5.6$ \\
\hline Ortaokul ve üstü & 98 & 30.2 & $27.4 \pm 5.3$ & $26.6 \pm 5.5$ & $17.9 \pm 5.5$ \\
\hline Test ve $p$ değeri & & & $\begin{array}{c}\mathrm{t}=-3.615 \\
\mathbf{p}<\mathbf{0 . 0 0 1}\end{array}$ & $\begin{array}{l}\mathrm{t}=1.894 \\
\mathrm{p}=0.059\end{array}$ & $\begin{array}{c}t=.097 \\
p=0.923\end{array}$ \\
\hline \multicolumn{6}{|l|}{ Yaşadığı kişi } \\
\hline Yalnız & 17 & 5.2 & $21.8 \pm 6.8$ & $26.7 \pm 5.6$ & $21.2 \pm 4.6$ \\
\hline Aile ile / diğer kişiler ile & 308 & 94.8 & $25.5 \pm 6.8$ & $27.4 \pm 4.7$ & $17.8 \pm 5.5$ \\
\hline Test ve $\mathrm{p}$ değeri & & & $\begin{array}{l}t=-2.156 \\
\mathbf{p}=\mathbf{0 . 0 3 2}\end{array}$ & $\begin{array}{c}t=-0.609 \\
p=0.543\end{array}$ & $\begin{array}{l}\mathrm{t}=2.484 \\
\mathbf{p}=\mathbf{0 . 0 1 4}\end{array}$ \\
\hline \multicolumn{6}{|l|}{ Ailedeki birey sayısı } \\
\hline $1-2$ & 111 & 34.2 & $23.8 \pm 7.2$ & $28.4 \pm 4.2$ & $19.0 \pm 4.3$ \\
\hline 3 ve üzeri & 214 & 65.8 & $26.1 \pm 6.5$ & $26.8 \pm 4.9$ & $17.4 \pm 6.0$ \\
\hline Test ve $\mathrm{p}$ değeri & & & $\begin{array}{l}t=-2.863 \\
p=\mathbf{0 . 0 0 4}\end{array}$ & $\begin{array}{l}t=2.796 \\
p=\mathbf{0 . 0 0 5}\end{array}$ & $\begin{array}{l}t=2.613 \\
p=0.009\end{array}$ \\
\hline
\end{tabular}

*Tukey HSD $\quad$ t: bağımsız gruplarda t testi $\quad$ F: tek yönlü varyans analizi




\begin{tabular}{|c|c|c|c|c|c|}
\hline & $\mathbf{n}$ & $\%$ & $\begin{array}{c}\text { İc Kontrol } \\
\text { Odağı } \\
\text { Ort } \pm \text { SS }\end{array}$ & $\begin{array}{c}\text { Güçlü Başkaları } \\
\text { Kontrol } \\
\text { Odağı } \\
\text { Ort } \pm \text { SS } \\
\end{array}$ & $\begin{array}{c}\text { Şans } \\
\text { Kontrol } \\
\text { Odağı } \\
\text { Ort } \pm \text { SS } \\
\end{array}$ \\
\hline \multicolumn{6}{|l|}{ Beden kitle indeksi } \\
\hline Normal $^{\mathrm{a}}$ & 23 & 7,1 & $23.9 \pm 5.9$ & $23.3 \pm 6.0$ & $15.2 \pm 4.3$ \\
\hline Hafif Kilolu $^{\mathrm{b}}$ & 164 & 50,5 & $25.5 \pm 7.0$ & $28.6 \pm 4.3$ & $18.5 \pm 5.5$ \\
\hline Obez $z^{c}$ & 138 & 42,5 & $25.4 \pm 6.8$ & $26.5 \pm 4.4$ & $17.8 \pm 5.6$ \\
\hline \multirow[t]{2}{*}{ Test ve p değeri } & & & $\mathrm{F}=0.523$ & $\mathrm{~F}=17.752$ & $\mathrm{~F}=3.673$ \\
\hline & & & $\mathrm{p}=0.593$ & $\begin{array}{c}\mathbf{p}<\mathbf{0 . 0 0 1} \\
\mathrm{a}<\mathrm{c}<\mathrm{b}, \mathrm{p}<0.005^{* *}\end{array}$ & $\begin{array}{c}\mathbf{p}=\mathbf{0 . 0 2 6} \\
a<b, c \\
p<0.05^{*}\end{array}$ \\
\hline \multicolumn{6}{|c|}{ Sigara kullanma durumu } \\
\hline Kullaniyor & 51 & 15.7 & $24.7 \pm 5.8$ & $26.6 \pm 3.3$ & $16.7 \pm 5.5$ \\
\hline Kullanmıyor/birakmış & 274 & 84.3 & $25.4 \pm 7.0$ & $27.5 \pm 4.9$ & $18.2 \pm 5.5$ \\
\hline \multirow[t]{2}{*}{ Test ve $p$ değeri } & & & $t=-0.679$ & $\mathrm{t}=-1.280$ & $\mathrm{t}=-1.786$ \\
\hline & & & $\mathrm{p}=0.498$ & $\mathrm{p}=0.201$ & $\mathrm{p}=0.075$ \\
\hline \multicolumn{6}{|c|}{ Düzenli egzersiz yapma durumu } \\
\hline Evet $^{\mathrm{a}}$ & 79 & 24.3 & $28.4 \pm 4.8$ & $29.4 \pm 4.4$ & $20.3 \pm 4.0$ \\
\hline Hayır $^{\mathrm{b}}$ & 171 & 52.6 & $22.6 \pm 7.2$ & $26.1 \pm 4.6$ & $17.9 \pm 5.6$ \\
\hline Bazen $^{c}$ & 75 & 23.1 & $28.2 \pm 5.2$ & $28.1 \pm 4.5$ & $15.6 \pm 5.9$ \\
\hline \multirow[t]{3}{*}{ Test ve p değeri } & & & $\mathrm{F}=32.942$ & $\mathrm{~F}=15.395$ & $\mathrm{~F}=14.63$ \\
\hline & & & $\mathrm{p}<0.001$ & $\mathbf{p}<0.001$ & $\mathrm{p}<0.001$ \\
\hline & & & $\mathrm{a}, \mathrm{c}>\mathrm{b} \mathrm{p}<0.001$ & $\mathrm{a}, \mathrm{c}>\mathrm{b}, \mathrm{p}>0.001$ & $\begin{array}{l}a>b>c \\
p<0.005\end{array}$ \\
\hline \multicolumn{6}{|c|}{ Düzenli diyabet diyeti uygulama durumu } \\
\hline Evet & 216 & 66.5 & $26.9 \pm 6.2$ & $28.0 \pm 4.2$ & $17.3 \pm 5.9$ \\
\hline Hayır & 109 & 33.5 & $22.1 \pm 7.0$ & $26.0 \pm 5.3$ & $19.2 \pm 4.6$ \\
\hline \multirow[t]{2}{*}{ Test ve $\mathrm{p}$ değeri } & & & $\mathrm{t}=6.362$ & $\mathrm{t}=3.792$ & $\mathrm{t}=-3.038$ \\
\hline & & & $\mathrm{p}<\mathbf{0 . 0 0 1}$ & p $<0.001$ & $\mathrm{p}=\mathbf{0 . 0 0 3}$ \\
\hline \multicolumn{6}{|c|}{ Düzenli sağlık kontrolü yaptırma durumu } \\
\hline Evet & 263 & 80.9 & $25.1 \pm 7.1$ & $28.0 \pm 4.6$ & $18.0 \pm 5.6$ \\
\hline Hayır & 62 & 19.1 & $26.0 \pm 5.5$ & $24.5 \pm 4.2$ & $17.6 \pm 5.5$ \\
\hline \multirow[t]{2}{*}{ Test ve $\mathrm{p}$ değeri } & & & $\mathrm{t}=-0.886$ & $\mathrm{t}=5.399$ & $\mathrm{t}=0.585$ \\
\hline & & & $\mathrm{p}=0.377$ & $\mathrm{p}<0.001$ & $\mathrm{p}=0.559$ \\
\hline
\end{tabular}

*Tukey HSD $\quad * *$ Dunnett T3 $\quad$ t: bağımsız gruplarda t testi $\quad$ F: tek yönlü varyans analizi

Hastaların, hastalık özelliklerine göre Çok Boyutlu Sağlı Kontrol Odağ 1 Ölçeği alt boyutlarının puan dağılımı incelendiğinde, $\dot{I} c ̧$ Kontrol Odağı alt boyutunda HbAlc düzeyi, diyabetle ilgili yeterli eğitim aldığını düşünme ve diyabet tedavi şeklinin puan ortalamalarının benzer olduğu $(p>0.05)$, ailede diyabet varllğı, diyabet eğitimi alma ve ilaçlarını düzenli kullanma durumunun anlamlı olduğu bulunmuştur $(p<0.05)$. Farklılığı saptamak için kullanılan Tukey HSD testine göre, birinci ve ikinci derece akrabalarında diyabet görülenlerin puan ortalamasının benzer olduğu ve ailede diyabeti olmayanların puan ortalamasının iki gruptan daha düşük olduğu bulunmuştur. Diyabet eğitimi almayanların

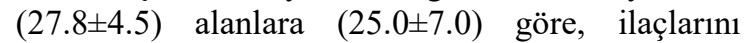
düzenli kullanmayanların (28.3 \pm 2.6$)$, kullananlara $(24.9 \pm 7,1)$ göre puanları yüksek bulunmuştur.
Güçlü Başkaları Kontrol Odağında HbA1c düzeyi, diyabet eğitimi alma ve ilaçlarını düzenli kullanma puan ortalamalarının benzer olduğu bulunmuştur $(p>0.05)$. Ailede diyabet varlığında ise ikinci derece akrabalarında diyabet görülenlerin puan ortalamasının gruplarla benzer olduğu, ailede diyabeti olmayanların puan ortalamasının ise birinci derece akrabalarında diyabet görülenlerinden yüksek olduğu belirlenmiştir. Diyabetle ilgili yeterli eğitim aldığını düşünenlerin (27.8 \pm 4.5$)$, düşünmeyenlere (26.4 \pm 5.4$)$ göre puan ortalaması yüksek bulunmuştur. Diyabet tedavi şeklinde ise, sadece insülin kullananlar ile insülin ile birlikte oral anti diyabetik kullananların puan ortalamalarının benzer olduğu ve her iki grubun puan ortalamasının sadece oral anti diyabetik kullananlara göre yüksek olduğu bulunmuştur. 
Şans kontrol odağında diyabet eğitimi alma durumu, diyabetle ilgili yeterli eğitim aldığını düşünme ve ilaçlarını düzenli alma durumu puan ortalamalarının benzer olduğu bulunmuştur ( $p>0.05)$. HbA1c düzeyi 8.2 ve daha düşük olanların arasında olanların $(18.9 \pm 5.3) 8.3$ ve üzeri olanlara $(15.7 \pm 5.1)$ göre puanı ortalaması yüksek bulunmuştur. Dunnett T3 testine göre, birinci ve ikinci derece akrabalarında diyabet görülenlerin puan ortalamasının benzer olduğu ve ailede diyabeti olmayanların puan ortalamasının iki gruptan daha yüksek olduğu bulunmuştur. Diyabet tedavi şeklinde ise sadece insülin kullananlar ile, insülin ile birlikte oral anti diyabetik kullananların puanlarının benzer olduğu, farkın sadece oral anti diyabetik kullananlardan kaynaklandığı ve puanının iki gruptan daha yüksek olduğu bulunmuştur (Tablo 4).

\begin{tabular}{|c|c|c|c|c|c|}
\hline & $\mathbf{n}$ & $\%$ & $\begin{array}{c}\text { İç Kontrol } \\
\text { Odağı } \\
\text { Ort } \pm \text { SS }\end{array}$ & $\begin{array}{c}\text { Güçlü Başkaları } \\
\text { Kontrol } \\
\text { Odağı } \\
\text { Ort } \pm \text { SS }\end{array}$ & $\begin{array}{c}\text { Şans Kontrol } \\
\text { Odağı } \\
\text { Ort } \pm \text { SS }\end{array}$ \\
\hline \multicolumn{6}{|l|}{ HbA1c Düzeyi (n=158) } \\
\hline 8.2 ve alt1 & 88 & 55.7 & $26.2 \pm 6.2$ & $27.2 \pm 5.1$ & $18.9 \pm 5.3$ \\
\hline 8.3 ve üzeri & 70 & 44.3 & $24.4 \pm 8.0$ & $26.7 \pm 4.9$ & $15.7 \pm 5.1$ \\
\hline Test ve p değeri & & & $\begin{array}{l}t=1.543 \\
p=0.125\end{array}$ & $\begin{array}{l}t=0.548 \\
n-0.584\end{array}$ & $\begin{array}{l}\mathrm{t}=3.845 \\
\mathbf{p}<\mathbf{0 . 0 0 1}\end{array}$ \\
\hline \multicolumn{6}{|l|}{ Ailede diyabet varlığı } \\
\hline Birinci derece akrabalarda ${ }^{a}$ & 97 & 29.8 & $26.4 \pm 6.3$ & $25.8 \pm 5.6$ & $16.9 \pm 6.1$ \\
\hline İkinci derece akrabalarda ${ }^{\mathrm{b}}$ & 52 & 16.0 & $26.4 \pm 7.0$ & $27.4 \pm 4.5$ & $15.2 \pm 5.6$ \\
\hline Yok $^{\mathrm{c}}$ & 176 & 54.2 & $24.4 \pm 7.0$ & $28.2 \pm 4.0$ & $19.3 \pm 4.8$ \\
\hline Test ve $p$ değeri & & & $\begin{array}{c}\mathrm{F}=3.638 \\
\mathbf{p}=\mathbf{0 . 0 2 7} \\
\mathrm{a}, \mathrm{b}>\mathrm{c}, \mathrm{p}<0.05^{*}\end{array}$ & $\begin{array}{c}\mathrm{F}=7.990 \\
\mathbf{n}<\mathbf{0 . 0 0 1} \\
\mathrm{c}>\mathrm{a}, \mathrm{p}<0.001 * *\end{array}$ & $\begin{array}{c}\mathrm{F}=14.66 \\
\mathbf{p}<\mathbf{0 . 0 0 1} \\
\mathrm{a}, \mathrm{b}<\mathrm{c} \\
\mathrm{p}<0.005^{* *}\end{array}$ \\
\hline \multicolumn{6}{|c|}{ Diyabet eğitimi alma durumu } \\
\hline Hayır & 40 & 12.3 & $27.8 \pm 4.5$ & $26.4 \pm 4.5$ & $16.8 \pm 4.0$ \\
\hline Evet & 285 & 87.7 & $25.0 \pm 7.0$ & $27.5 \pm 4.7$ & $18.1 \pm 5.7$ \\
\hline Test ve $p$ değeri & & & $\begin{array}{l}t=2.481 \\
\mathbf{p}=\mathbf{0 . 0 1 4}\end{array}$ & $\begin{array}{l}\mathrm{t}=-1.372 \\
\mathrm{n}=0171\end{array}$ & $\begin{array}{l}\mathrm{t}=-1.404 \\
\mathrm{p}=0.161\end{array}$ \\
\hline \multicolumn{6}{|c|}{ Diyabetle ilgili yeterli eğitim aldığını düşünme $(\mathrm{n}=\mathbf{2 8 5})$} \\
\hline Evet & 219 & 76.8 & $25.4 \pm 6.7$ & $27.8 \pm 4.5$ & $18.2 \pm 5.8$ \\
\hline Hayır & 66 & 23.2 & $23.5 \pm 8.1$ & $26.4 \pm 5.4$ & $17.8 \pm 5.5$ \\
\hline Test ve $p$ değeri & & & $\begin{array}{l}\mathrm{t}=1.890 \\
\mathrm{n}=0.060\end{array}$ & $\begin{array}{l}\mathrm{t}=0.061 \\
\mathbf{n}=\mathbf{0 . 0 4 0}\end{array}$ & $\begin{array}{l}t=0.530 \\
p=0.597\end{array}$ \\
\hline \multicolumn{6}{|l|}{ Diyabet tedavi şekli } \\
\hline Sadece oral anti diyabetik ${ }^{\mathrm{a}}$ & 225 & 69.2 & $25.0 \pm 6.2$ & $26.6 \pm 4.8$ & $18.9 \pm 5.0$ \\
\hline Sadece insülin ${ }^{\mathrm{b}}$ & 63 & 19.4 & $25.8 \pm 7.5$ & $29.5 \pm 4.1$ & $16.1 \pm 5.6$ \\
\hline $\begin{array}{l}\text { İnsülin ile birlikte oral anti } \\
\text { divabetik }^{\mathrm{c}}\end{array}$ & 37 & 11.4 & $26.4 \pm 9.0$ & $28.5 \pm 4.0$ & $15.2 \pm 7.0$ \\
\hline Test ve $p$ değeri & & & $\begin{array}{l}F=0.896 \\
p=0.409\end{array}$ & $\begin{array}{c}\mathrm{F}=11.273 \\
\mathbf{p}<\mathbf{0 . 0 0 1} \\
\mathrm{b}, \mathrm{c}>\mathrm{a}, \mathrm{p}<0.001 *\end{array}$ & $\begin{array}{c}\mathrm{F}=11.73 \\
\mathbf{p}<\mathbf{0 . 0 0 1} \\
\mathrm{a}>\mathrm{b}, \mathrm{c} \\
\mathrm{p}=0.00^{* *}\end{array}$ \\
\hline \multicolumn{6}{|c|}{ İlaçlarını düzenli alma durumu } \\
\hline Evet & 286 & 88.0 & $24.9 \pm 7.1$ & $27.4 \pm 4.7$ & $18.0 \pm 5.3$ \\
\hline Hayır & 39 & 12.0 & $28.3 \pm 2.6$ & $26.8 \pm 4.5$ & $17.5 \pm 7.0$ \\
\hline Test ve p değeri & & & $\begin{array}{l}\mathrm{t}=-2.902 \\
\mathbf{p}=\mathbf{0 . 0 0 4}\end{array}$ & $\begin{array}{l}t=0.797 \\
p=0.426\end{array}$ & $\begin{array}{l}\mathrm{t}=0.562 \\
\mathrm{p}=0.575\end{array}$ \\
\hline
\end{tabular}




\section{*Tukey HSD $\quad * *$ DunnettT3 $\quad \mathrm{t}$ : bağımsız gruplarda t testi $\quad \mathrm{F}$ : tek yönlü varyans analizi}

\section{TARTISMA}

Katılımcıların, Çok Boyutlu Sağlık Kontrol Odağı Ölçeği'nden aldıkları puanlar incelendiğinde; İç

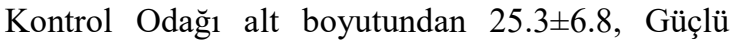
Başkaları Kontrol Odağı alt boyutundan 27.3 \pm 4.7 , Şans Kontrol Odağı alt boyutundan $17.9 \pm 5.5$ puan aldığ 1 belirlenmiştir (Tablo 1). Çalışmadaki bu göstergelerle diyabetli bireylerin hastalık yönetiminde, dışsal kuvvetlere daha çok inanma eğiliminde olduğu görülmektedir. Diyabetli hastalarda yapılan diğer çalışmalar incelendiğinde, Al Nawafa'h ve Hamdan-Mansour (2015); iç kontrol odağından 27.2 \pm 6 , güçlü başkaları kontrol odağından $30.8 \pm 5.2$, şans kontrol odağından 15.6 \pm 6.6 puan $^{8}$, Aflakseir ve ZarrinPour (2014) sirasiyla $26.0 \pm 4.2, \quad 24.9 \pm 4.6, \quad 20.9 \pm 5.9 \quad$ puan $^{20}$, Williams ve arkadaşları (2016) 25.9 $\pm 5.6,23.7 \pm 5.6$, $17.4 \pm 5,9$ puan $^{11}$ aldıklarını belirlemişlerdir. Zahednezhad ve arkadaşları (2011); 27.9 \pm 6.3 , $18.88 \pm 6.56, \quad 25.30 \pm 5.59$ olarak $^{9}$ bulmuştur. Çalışmalarda, diyabeti olan bireylerin genellikle iç kontrol ve güçlü başkaları kontrol odaklarının yüksek olduğu gözlemlenmiştir. ${ }^{14,21}$ Ülkemizde ise diyabet hastalarının kontrol algılarına yönelik sınırlı sayıda çalışmaya ulaşılmıştır. Bireylerin, iç kontrol odaklarının güçlü başkaları kontrol odağına yakın olması bireylerin hastalık algısının yüksek olmasıyla açıklanabilir. Hastalığın kronik olması, komplikasyonlar oluşturması nedeniyle de bireyler başka kişilerin yardımına ihtiyaç duyabilmekte ve bu da güçlü başkaları kontrol odağının yüksek olmasına neden olabilmektedir. Ayrıca yapılan çalışmalarda güçlü başkaları kontrol odağı ve iç kontrol odağının önceliklerinin değişken olmasının eğitim ve sosyokültürel farklılıklar nedeniyle olduğu düşünülmüştür.

Yüksek iç kontrol odağına sahip olan hastaların tedavi ile uyum oranlarının ve kendi sağlıklarına olan inançlarının daha fazla olduğu söylenebilir. ${ }^{7,9}$ İç kontrolü yüksek olan bireylerin, diyetlerine daha çok dikkat ettiklerini gösteren çalışma mevcutken ${ }^{13}$, diyete uyumu etkilemediğini belirten çalışmada mevcuttur. ${ }^{20}$ Aynı şekilde, iç kontrol odağının öz-etkililik puan ortalamasıyla pozitif yönde bir anlamllık gösterdiği bulunmuştur. ${ }^{14}$ Ayrıca iç kontrolün yaş ${ }^{22}$, ekonomik durum $^{22-24}$ fiziksel-mental sağllk ve sağlık davranışları ile ilişkili olduğu da $\mathrm{da}^{25}$ bildirilmiştir. Yaş ile iç kontrol odağı arasındaki ilişkide anlamlılık saptanmayan çalışmalar mevcutken ${ }^{20-26}$, Poortinga ve ark (2008) çalışmasında ${ }^{23}$ ise 35-64 yaş arasındaki bireylerin daha yüksek iç kontrol odağına sahip oldukların bildirmiştir. Abredari ve ark (2015) çalışmasında ${ }^{24}$ ise yaş arttıkça erkeklerin iç kontrol odağının geliştiğini belirtmiş ve çeşitli çalışmalarda erkeklerin daha yüksek iç kontrole sahip oldukları bildirilmiştir. ${ }^{12,23,26}$ Medeni durum değerlendirildiğinde çalıșmamıza paralel olarak evli bireylerin iç kontrol odak puanının daha yüksek olduğunu destekleyen çalışma bulunmaktadır. ${ }^{26}$ İç kontrol odağ1 güçlü olan bireylerin karşılaştıkları sorunların kendi kişilik özelliklerinden kaynakladığını düşünmeleri, başarıya ulaşmak için çaba göstermeleri kendi motivasyonlarını arttırabilir. Ayrıca, çalışmaya alınan hastaların iç kontrol odağı puanının çok yüksek olmamasının nedeni grubun yaş ortalamasının orta düzey ve eğitim seviyesinin düşük olması ile açıklanabilir. Tıbbi tedavi alt boyutunda anlamlılık bulunmaması, hastaların istenilen ilaç prosedürüne uyması ve tedavi boyutunda zorlu bir davranış gerektirmemesi ile açılanabilir.

Hemşirelerin ve hastaların kontrol algılarının karşılaştırıldığı bir çalışmada; hemşirelerin ve hastaların dış kontrol odağına daha çok sahip oldukları görülmüştür. ${ }^{8}$ Aflakseir ve ZarrinPour'un (2014) çalışmasında, ${ }^{20}$ dış kontrol odağına sahip kişilerin diyete uyum eğilimleri yüksek iken, şans odağına sahip kişilerin daha az uyum gösterme eğiliminde oldukları görülmüştür. Grotz ve ark. (2011), yetişkin Alman popülasyonunda yaptıkları çalışmada ${ }^{27}$ yaşlı bireyler, düşük sosyoekonomik düzeye sahip olanlar ve göç yoluyla gelenlerin daha çok güçlü başkaları ve şans odağına sahip oldukları bulunmuş aynı çalışmada şans sağlık odağının fiziksel aktivite, diş sağlığı, düzenli muayenelere gitmek gibi sağlıklı davranışlarla daha az ilişkili olduğu bildirilmiştir. Poortinga ve ark. (2008) çalışmasında ${ }^{23}, 45-74$ yaş arasındaki bireylerin güçlü başkaları odak puanının giderek arttığ 1 ve 65-74 yaş arasındaki bireylerin şans kontrol odak puanlarının daha yüksek olduğu bildirilmiştir. Fuscaldive ark. (2011) çalışmasında ${ }^{21}$ kadınların erkeklere göre şans alt boyutundan aldıkları puanın istatistiksel olarak daha yüksek olduğu görülmüştür.

Aynı şekilde, Morowatisharifabad ve ark. (2010) çalışmalarında ${ }^{12}$ kadınların şans kontrol odağı alt boyutundan aldıkları puanın erkeklere oranla daha fazla olduğu ve cinsiyetin, güçlü başkaları kontrol odağı üzerinde bir anlamlılık oluşturmadığı belirtilmiştir. Dış kontrol odağı ve şans kontrol odağını kullanan bireylerin bütün başarısızlıklarının kendi kontrollerinin dışında olduğunu düşünmeleri nedeni ile motivasyonlarının daha az olduğu söylenebilir. Ayrıca dini tutum veya inancı yüksek olan bireylerin içinde bulundukları sosyokültürel ortamı da denetim odağını etkilemektedir. Bazı insanların daha kaderci bir tutuma sahip olmaları nedeni ile şans odağını kullanan bireylerin yetersiz sağlık davranışları açısından bir risk faktörü olarak ele alınması gerektiği ve şansın sağlık davranışları üzerinde dolaylı bir etkileşimi olabileceği de 
unutulmamalıdır.

\section{Araștırmanın Sınırlılıkları}

Bu çalışma, üç aile sağlığı merkezine başvuran tip 2 diyabetli bireyler ile yapıldığından örneklem sınırlılığı içermektedir. $\mathrm{Bu}$ nedenle çalışma sonuçları evrene genellenemez.

\section{SONUÇ VE ÖNERILER}

Katılımcıların iç kontrol, güçlü başkaları ve şans kontrol odakları arasından güçlü başkaları kontrol odağından aldıkları puanın daha yüksek olduğu ve bu odağın da çeşitli faktörlerden (yaş, BKİ, egzersiz yapma durumu gibi) etkilendiği saptanmıştır. Hemşireler, diyabetli bireylerin sağlık algılarını belirleyerek hastaların kendi sağlıklarını yönetebilmelerini desteklemelidir. Hasta ile etkin bir işbirliği yapmalı ve hastalıklarında etkin bir rol oynamalarını sağlamalıdır. Çalışmanın daha geniş örneklem grubuyla tekrar edilmesi, yapılan fiziksel aktivitenin türünün, süresinin ve sıklığının incelenmesi önerilir.

Teşekkür: Çalışmanın istatistiksel analizlerinde destek olan Doç. Dr. Deniz TANYER'e teşekkür ederiz.

\section{KAYNAKLAR}

1. Schunk DH. Öğrenme teorileri: eğitimsel bir bakışla. Şahin M, çev.editör. 5. Baskı. Ankara:Nobel Akademik Yayıncılık; 2014, p. 492-494.

2. Rotter J. Generalized expectancies for internal versus external control of reinforcement. Psychological Monographs: General and Applied 1966; 80: 1-28.

3. Küçükkaragöz H, Akay Y, Canbulat T. Rotter iç-dış kontrol odağ1 ölçeğinin öğretmen adaylarında geçerlik ve güvenirlik çalışması. Akademik Bakış Dergisi, 2013;35:1-12.

4. O'hea E, Moon S, Grothe K, Boudreaux E, Bodenlos J, Wallston K, et al. The interaction of locus of control, self-efficacy, and outcome expectancy in relation to $\mathrm{HbA} 1 \mathrm{c}$ in medically underserved individuals with type 2 diabetes. J Behav Med 2009; 32:106-17. doi: 10.1007/s10865-008-9188-x

5. Yeşilyaprak B. Eğitim psikolojisi: gelişim, öğrenme-öğretim. Ankara: Pegem Akademi Yayınları; 2012: 245-69.

6. Trento M, Tomelini M, Basile M, Borgo E, Passera P, Miselli V et al. The locus of control in patients with type 1 and type 2 diabetes managed by individual and group care. Diabet Med 2008; 25: 86-90 doi: 10.1111/j.14645491.2007.02319.x
7. Przybylski M. Health locus of control theory in diabetes: a worthwhile approach in managing diabetic foot ulcers? Journal of Wound Care 2010; 19: 228-33 doi: 10.12968/jowc.2010.19.6.48470

8. Al Nawafa'h A, Hamdan-Mansour A. Correlates of health locus of control among patients diagnosed with type-ii diabetes mellitus. Journal of Diabetes Mellitus 2015; 5: 190-7 doi: $10.4236 / j d m .2015 .53023$.

9. Zahednezhad H, Poursharifi H, Babapour J. Memory, health locus of control and adherence in type ii diabetic patients in Iran - Tabriz. Procedia - Social and Behavioral Sciences, 2011; 30: 2621-4 https://doi.org/10.1016/j.sbspro.2011.10.513

10. Keedy N, Keffala V, Altmaier E, Chen J. Health locus of control and self-efficacy predicted back pain rehabilitation outcomes. The Iowa Orthopaedics and Rehabilitation 2014; 34: 15865.

11. Williams J, Lynch C, Voronca D, Egede L. Health locus of control and cardiovascular risk factors in veterans with type 2 diabetes. Endocrine 2016; 51:83-90 doi: 10.1007/s12020-015-0677-8.

12. Morowatisharifabad M, Mahmoodabad S, Baghianimoghadam M, Tonekaboni N. Relationships between locus of control and adherence to diabetes regimen in a sample of iranians. Int J Diabetes Dev Ctries 2010; 30: 27 32.

13. Cobb-Clark D, Kassenboehmer S, Schurer S. Healthy habits: the connection between diet, exercise, and locus of control. Journal of Economic Behaviour and Organization 2014;98:1-28 https://doi.org/10.1016/j.jebo.2013.10.011.

14. Chen S, Lin H. Relationships among health locus of control, psychosocial status and glycemic control in type 2 diabetes adults. Journal of Nursing and Care 2014:1-6 doi:10.4172/2167-1168.1000162.

15. Cohen J, Cohen P, West SG, Aiken LS. Applied multiple regression/correlation analysis for the behavioral sciences. 3rd edition:Mahwah NJ: Lawrence Earlbaum Associates; 2003:19-64.

16. Erol O, Enc N. Hypoglicemia fear and selfefficacy of Turkish patients receiving insulin therapy. Asian Nursing Research 2011;5:222228.

17. Akpunar D. Diyabet eğitiminin hastaların sağlık inancına, bilgi düzeyine ve diyabet yönetimine etkisi, Atatürk Üniversitesi:Sağl1k Bilimleri Enstitüsü, Yükseklisans Tezi. Erzurum: 2012:51-67.

18. Wallston K, Wallston B, DeVellis R. Development of the multidimensional health locus of control (MHLC) scales. Health Education Monographs 1978; 6: 160-70. 
19. Üstündağ-Budak M, Mocan-Aydın G. The role of personality factors in predicting the reported physical health symptoms of Turkish college students. Adolescence 2005; 40: 559-72.

20. Aflakseir A, ZarrinPour R. Predicting adherence to diet regimen based on health locus of control: a cross sectional study. Iranian Journal of Diabetes and Obesity 2014; 5: 71-6.

21. Fuscaldi F, Balsanelli A, Grossi S. locus of control in health and self-esteem in type-2 diabetic patients. Rev Esc Enferm USP 2011; 45: 853-9 http://dx.doi.org/10.1590/S008062342011000400009.

22. Lindström M, Rosvall M. Marital status, social capital and health locus of control: a populationbased study. Public Health 2012; 126: 790-5 doi: 10.1016/j.puhe.2012.06.001.

23. Poortinga W, Dunstan F, Lone D. Health locus of control beliefs and socio-economic differences in self-rated health. Preventive
Medicine 2008; 46: 374-80 doi: 10.1016/j.ypmed.2007.11.015.

24. Abredari H, Bolourchifard F, Rassouli M, Nasiri N, Taher M, Abedi A. Health locus of control and self-care behaviours in diabetic foot patients. Medical Journal of the Islamic Republic of Iran 2015; 29:1-5.

25. Keedy N. Health locus of control, self-efficacy, and multidisciplinary intervention for chronic back pain. The Iowa Orthopaedic Journal 2009;34:158-165.

26. Bell RA, Quandt SA, Arcury TA, McDonald J, Vitolins MZ. Health locus of control among rural older adults. Gerontology \& Geriatrics Education 2002;22:69-89 http://dx.doi.org/10.1300/J021v22n04_06.

27. Grotz M, Hapke U, Lampert T, Baumeister H. Health locus of control and health behaviour: results from a nationally representative survey. Psychol Health Med 2011; 16: 129-40 doi: 10.1080/13548506.2010.521570. 